\title{
SAFETY NEEDS OF PRODUCT USERS
}

\author{
Widomar Pereira Carpes Júnior, Dr. Eng. \\ Departamento de Metal-Mecânica, Centro Federal de Educação Tecnológica, \\ Florianópolis, Santa Catarina, Brazil
}

\section{Ingeborg Sell, Dr. rer.nat.}

Engenharia de Produção, Universidade Regional de Blumenau, Blumenau, Santa Catarina, Brazil

Este artigo apresenta um método para a determinação das necessidades de segurança dos consumidores de produtos, que nem sempre são fáceis ou simples de determinar. Este método é composto por etapas analíticas e sintéticas, cujo resultado é a lista de necessidades de segurança, que serão agrupadas com as outras necessidades determinadas pelo projetista, possibilitando o desenvolvimento de produtos mais seguros.

Palavras-chave: Metodologia de Projeto; Projeto de Produto; Segurança de Produtos.

This paper presents a method for determining safety needs for product users, something seldom easy to determine. This method is comprised of analytical steps and their synthesis, resulting in a list of safety needs that will be grouped with other needs raised by the authors enabling development of safer products.

Keywords: Design Methodology; Product Design; Product Safety.

\section{Introduction}

There exist various methodologies for designing products that have as their objective the transformation of users' needs, desires or requirements into product specifications, all with the aim of customer satisfaction.

Needs, wishes or requirements related to performance and dimensions, for example, are tangible and measurable and are thus easily transformed into product specifications. Safety needs are much more difficult to transform into such 
specifications since, many times, they are neglected during the design of these products. This negligence on the part of the designers owes itself to a lack of adequate design methods explicitly regarding safety and also to cultural aspects, in which the operator is the first person to be 'blamed' for an accident; either he or she must have been inattentive or did not have take appropriate precautions. If the operator is blamed there is no need to improve the product or study accidents in depth.

\section{Method for Determining the Safety Needs of Users}

Users or users hope that products have an acceptable safety level. Many times however, this desire is difficult to translate into expressions that may be utilized in the house of quality (QFD) and, consequently, transformed into measurable properties of the product, i.e. into design prerequisites of the product. With the aim of improving obtainment of these expressions, a method was created for determining the safety needs of users in relation to the product, structured in 7 stages and represented in figure 1, in which the resources to be used are also indicated.

\subsection{Identifying Product Safety Problems}

The objective in identifying possible safety problems is to enable comprehension of how factors or conditions are interacting with the product and endangering safety, thus permitting greater understanding of the product in the conditions in which it is used. Safety problems may be defined as a description of some thing or circumstance capable of provoking accidents, with negative consequences to the user. This is the first description of a problem and thus tends to be vague and abstract; in the run-down of the application of the method it will become more specific and objective.

Definition of product safety problems uses information derived from four sources: the design process of the product, accident reports, analysis of similar products and interviews with users. This action is initiated after a proposal for a new product has been formulated, making it necessary to identify possible problems that 
may appear when it is consumed or used; the latter includes operation, maintenance and cleaning. From the moment that the user market, geographical region and characteristics of the user, among others, are determined, safety problems become restrictive and definitive.

In the case of totally new products, for which neither similar products nor accident reports exist, we may resort to alternative means of technical induction such as brainstorming and the 635 method in order to identify possible safety problems. Use of such procedures offers a viable determination of any hazardous possibility imaginable for a particular product when information from other sources is not available. The identification of hazards must be realized, preferably, by a team of designers. In relation to the identification of safety problems we must also consider difficulties in the perceptions of the designer. In general, they become so familiar with their projects that they do not perceive problems and difficulties that may arise for the user. It is thus the designer who must thus start identifying safety problems, seeking to understand the environmental and human conditions at work on the product, besides the characteristics of the product itself.

Environmental conditions represent the circumstances to which the product will be exposed, owing to the nature of the user environment. This environment can vary from open environments, in which products would be exposed to climactic and weather impacts, to closed, in which atmosphere and temperature are both rigidly controlled. For example, exposure of a product to rain can result in electrical problems that would never occur if the product were located in a closed environment. 


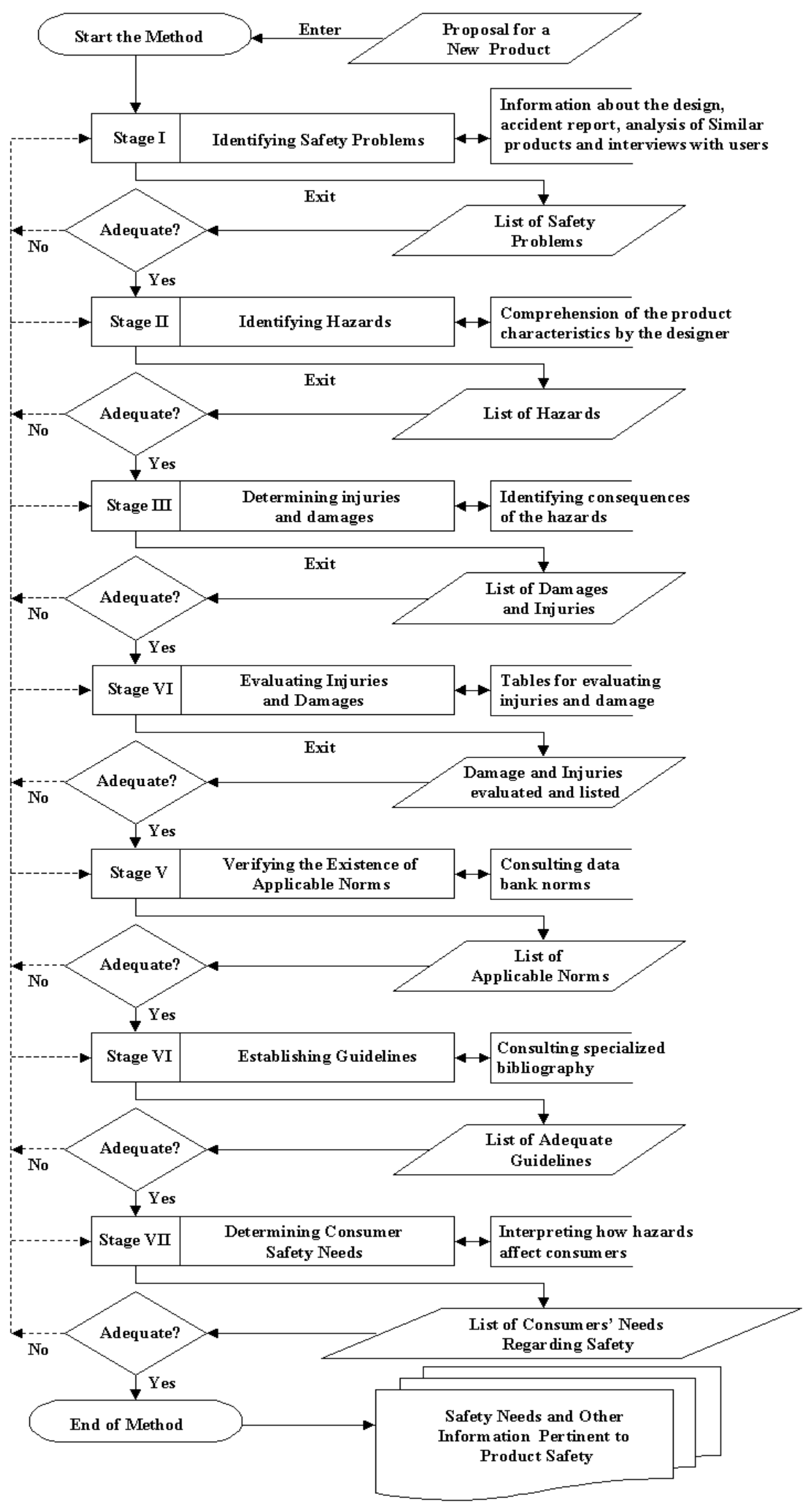

Figure 1 - Flowchart of the method for determining safety needs. 
Human conditions result from the psychological, physiological, ethnic, and intellectual characteristics of the products' users. In order to identify these characteristics we must determine the potential users, who may include people that have physical and psychological limitations which could affect their using the product safely. For example: when the user group includes children, the product must not contain small parts that could be ingested by children. In sum, a determination must be made about the product users regarding their training, ability, education, sex and age in order to facilitate anticipation of risks and to reassert the necessity of reducing hazards. Defining the conditions in which a product will be used enables identification of various problems resulting from interactions between the user and the product, such as the use of warnings for illiterate users or ones that cannot understand numbers. Once these conditions are defined, they may be followed by identification of hazards.

Besides the safety problems cited above, there are those that are inherent in the function of the product itself, such as the generation of heat, use of electrical energy, the presence of sharp edges and other hazards. Execution of multiple tasks inevitably necessitates in intrinsically unsafe solutions.

After their identification, safety problems are divided into 3 groups:

- Environmental Group: formed by interactions between the environment and the product, which can result in accidents because of the product being affected. In this group are problems resulting from environmental conditions such as rain, cold, solar radiation and temperature;

- Operational Group: formed by interactions that occur between the product and the user, including operational activities, maintenance and cleaning;

- Product Group: formed by any inherently hazardous characteristics of the product itself.

The result of this stage is a list relating the safety problems of the product that enables identification of the hazards associated with these problems, as presented in table 1 . 
Table 1 - Example of product safety problems

\section{Safety Problems}

\section{Environmental Group:}

Humidity causing electrical shocks to the operator.

Liquids on the hoses freezing from cold, provoking accidents.

Warnings fading and becoming illegible, after exposure to sunlight.

\section{Operational Group:}

Feeding the machine exposes the operator to the cutting tool.

Bruises on the hands result from little space for maintenance.

Machine remains on during cleaning, exposing the operator to the gear mechanism.

Product Group:

The product has parts that heat up.

The product is not grounded.

The product has sharp, cutting edges in its structure.

\subsection{Identifying Hazards in the Product}

The objective of this stage is to convert or transform the generic descriptions of the product's safety problems into descriptions of its characteristic hazards (including operational and environmental interactions), making them more concrete and objective and associating them to the sub-systems and components of the product.

The hazards existent in products encourage accidents that result in damage and lesions. These characteristics are consequences of the product, of the interactions in its operation or from the action of the environment on the product. In truth, there are no rigid rules for recognizing hazards as these present themselves in different ways. Therefore, the accident report is one source of information for the identification of problems in product safety that can deduce the contributing hazards, conditions and factors that result in accidents; this information is also useful in evaluating similar products still not in use. When there is no accident report, identification of hazard can be realized through identification of product elements that may affect safety. In this work, hazards are divided into groups with similar characteristics in order to make them more easily identifiable. There are three main groups: the group of hazards inherent to the product, the operational group formed by interaction between humans and the machine and the environmental group formed by 
undesirable interactions between the product and the environment. These groups are represented in table 2.

Together with the identification of hazard, the product's components or subsystems that present hazard must also be determined. All hazards originate in the characteristics of the product, which are determined in its design. Even operational and environmental hazards are generated by the constitution and characteristics of the product, such as in the configuration of components and sub-systems and the materials used. Table 3 shows examples of product hazards, related to their own characteristics, derived from such diverse factors as constitution of materials and mechanical components, for example.

Table 2 - Classification of hazards

\begin{tabular}{|l|l|l|}
\hline Classes of Hazard & \multicolumn{1}{|c|}{ Description } & \multicolumn{1}{c|}{ Examples } \\
\hline Product & $\begin{array}{l}\text { Physical, chemical or biological } \\
\text { characteristics } \\
\text { Existent in the product. }\end{array}$ & $\begin{array}{l}\text { Electrical energy, heated } \\
\text { parts, vibrations and toxic } \\
\text { substances. }\end{array}$ \\
\hline Operational & $\begin{array}{l}\text { Resulting from interactions } \\
\text { between humans and machines } \\
\text { when the product is in use, } \\
\text { maintenance and cleaning. }\end{array}$ & $\begin{array}{l}\text { Lack of protection, } \\
\text { inadequate warnings, } \\
\text { inadequate dimensions, } \\
\text { difficulties in operation, } \\
\text { maintenance and cleaning, } \\
\text { poor allocation of } \\
\text { functions and need for } \\
\text { much training. }\end{array}$ \\
\hline Environmental & $\begin{array}{l}\text { Due to interactions between the } \\
\text { product and the environment. }\end{array}$ & $\begin{array}{l}\text { Freezing, thermal tension } \\
\text { and grinding due to dust. }\end{array}$ \\
\hline
\end{tabular}

Table 3 - Examples of inherent hazards in products

\begin{tabular}{|l|l|}
\hline \multicolumn{1}{|c|}{ Product Hazard } & \multicolumn{1}{c|}{$\begin{array}{c}\text { Sub-systems or } \\
\text { Components that present } \\
\text { hazard }\end{array}$} \\
\hline Cutting edges & Saw \\
\hline Movable parts & Transmission sub-system \\
\hline Falling objects & Transport chain \\
\hline Electrical shock & Electrical sub-system \\
\hline Ignition of combustibles & Fuel sub-system \\
\hline Unexpected activation & Control sub-system \\
\hline Explosive liquid & Fuel tank \\
\hline Hot surfaces (burns) & Motor \\
\hline High noise level & Motor \\
\hline Fragments or projectiles & Saw \\
\hline
\end{tabular}


Of all types of hazard related to products, the operational group is the most complex and requires special attention on the part of the designer. Interactions between humans and machines relate directly to errors in operation, maintenance and cleaning. These errors are consequences of the allocation of inappropriate functions, resulting in a lack of consideration of human capacities, abilities and limitations or rather, they occur when the product induces error in the operator, compromising the user-product system. Examples of operational hazards are found in table 4.

The group of environmental hazards consists of possible alterations or changes in product performance may present due to inclement weather or incongruity between the environment foreseen during the design phase and the actual environment. If the environmental possibilities were not completely understood and considered during the design phase they will prejudice the product and the performance of its functions. Examples of environmental hazards are found in table 5.

Table 4 - Examples of Operational Hazards in Products

\begin{tabular}{|l|l|}
\hline \multicolumn{1}{|c|}{ Operational Hazards } & $\begin{array}{l}\text { Subsystems or Components } \\
\text { Related with Hazard }\end{array}$ \\
\hline Hazardous feed of the product & Feed subsystem \\
\hline Involuntary activation & On/off key \\
\hline $\begin{array}{l}\text { Inadequate or poorly dimensioned } \\
\text { commands and dials }\end{array}$ & Control subsystem \\
\hline Difficulty in access & Cabinet \\
\hline Discomfort during operation & Structure \\
\hline Maintenance com product in use & Transmission subsystem \\
\hline Removable protections during operation & Saw \\
\hline
\end{tabular}

Table 5 - Examples of Environmental Hazards of Products

\begin{tabular}{|l|l|}
\hline \multicolumn{1}{|c|}{ Environmental Hazards } & $\begin{array}{c}\text { Subsystems or Components } \\
\text { Related to the Hazard }\end{array}$ \\
\hline Condensation & Long air tubes \\
\hline Freezing of fluids & Hydraulic brake \\
\hline Corrosion or deterioration of components & Structure \\
\hline Grinding of parts due to dust & Transmission subsystem \\
\hline Breaks or thermal ruptures & Structure \\
\hline Excessive humidity & Electrical subsystem \\
\hline Vaporization & Fuel tank \\
\hline
\end{tabular}


Environments can also affect the product over the long term, including slow reactions that cause damage losses in the functional capacity of the product, many times as a result of a combination of various concomitant environmental factors. For example, the problem of metal corrosion increases considerably with an increase in temperature that, in turn, reduces relative humidity. It is then necessary to take advantage of this joint occurrence of factors in order to analyze their possible consequences.

A worthwhile observation to make here is that when products within the same area are designed regularly, it is possible to create and use verification lists, which are applied in recognizing hazards in similar products, ones that are already on the market. This action can indicate safety problems in the competition and demonstrate, inclusively, similar, recurring problems in various products of the same area, facilitating the work of the designer.

\subsection{Determining Possible Injuries and Damage}

In this stage possible lesions and injuries are determined, listing them (see the examples in tables 6, 7 and 8), or rather, determining which personal, monetary and environmental prejudices each hazard associated with the product can provoke in case of an accident. For each hazard identified in an earlier phase, the possible consequences in terms of prejudice to people's health, along with monetary and environmental and monetary loss, are determined.

Table 6 - Examples of injuries resulting from hazards of a product

\begin{tabular}{|l|l|l|}
\hline \multicolumn{1}{|c|}{ Injuries } & \multicolumn{1}{|c|}{ Hazards } & \multicolumn{1}{c|}{$\begin{array}{c}\text { Subsystems or } \\
\text { Components }\end{array}$} \\
\hline Contusion & Falling objects & Transport chain \\
\hline Cuts & Sharp edges & Saw \\
\hline Crush injuries & $\begin{array}{l}\text { Maintenance with the product } \\
\text { turned on }\end{array}$ & Transmission subsystem \\
\hline Broken bones & Hazardous feeding & Feeding system \\
\hline Particles in the eyes & Fragments or projectiles & Saw \\
\hline Death & Electric shock & Electrical subsystem \\
\hline Thermal burns & Ignition of combustibles & Power subsystem \\
\hline Deafness & High noise level & Motor \\
\hline
\end{tabular}


Table 7 - Examples of environmental damage resulting from hazards in products

\begin{tabular}{|l|l|l|}
\hline Environmental Damage & \multicolumn{1}{|c|}{ Hazards } & \multicolumn{1}{c|}{$\begin{array}{c}\text { Subsystem or } \\
\text { Components }\end{array}$} \\
\hline $\begin{array}{l}\text { Atmospheric } \\
\text { Contamination }\end{array}$ & Vaporization & Fuel tank \\
\hline Soil Contamination & Leaking of hydraulic fluid & Brake subsystem \\
\hline Water contamination & Leaking of lubricating oil & Transmission subsystem \\
\hline Destruction of vegetation & Ignition of combustible & Power subsystem \\
\hline $\begin{array}{l}\text { Heating of the } \\
\text { environment }\end{array}$ & Liberation of gases & Motor \\
\hline
\end{tabular}

Table 8 - Examples of monetary prejudices resulting from hazards in products

\begin{tabular}{|l|l|l|}
\hline \multicolumn{1}{|c|}{ Monetary Prejudice } & \multicolumn{1}{|c|}{ Hazards } & \multicolumn{1}{c|}{$\begin{array}{c}\text { Subsystem or } \\
\text { Components }\end{array}$} \\
\hline Indemnities & High noise level & Motor \\
\hline Loss of material & Leakage & Fuel tank \\
\hline Loss of sales & Deficient software control & Control subsystem \\
\hline Excessive maintenance & Leakage of lubricating oil & Transmission subsystem \\
\hline Stopped product & $\begin{array}{l}\text { Corrosion or deterioration } \\
\text { of components }\end{array}$ & Structure \\
\hline Stopped operator & $\begin{array}{l}\text { Discomfort during } \\
\text { operation }\end{array}$ & Structure \\
\hline
\end{tabular}

\subsection{Evaluating Injuries and Damage}

In the evaluation of injuries and damage, and the possibility of accidents occurring to which they may be related, utilize tables 9 to 14 . Information about the consequences and the possibilities of accidents are obtained through interviews with users or through accident reports, in the case of products already existing and in use. In the case of products in development, without similar ones in use, the greatest effort must be made to try to foresee possible consequences and the possibility of future accidents, relating them to hazards. To do so means it is necessary to simulate accidents connected to the product, relating them to the product's hazards, enabling one to characterize any possible injuries or damage. For example, a kitchen knife possesses a cutting edge that, in case of accident, normally results in cuts to a user's hands. In this case, we have the number of people injured to the number of users (PE 
$=2)$, which is something that can occur frequently as the hazard is exposed $(\mathrm{PO}=$ 10). The other parameters are equal to zero.

Evaluation of a product's hazards is thus realized with the aid of information originating in the design process of the product, accident reports, analysis of similar products and interviews with users. This information is observed, after it is verified with the various, identified hazards that have been configured, in terms of the possibility of provoking accidents and producing undesirable consequences.

Evaluation of hazards is comprised of four parameters measured and evaluated by the designer, according to his knowledge regarding accidents and the product: the possibility of occurrence, and the personal, monetary and environmental impacts involved. The possibility of occurrence indicates the probability of the accident happening, as a result of the hazards involved. The personal parameter identifies the number of people that might be impacted and the severity of any injuries. The monetary parameter identifies the probable value of monetary damages, in relation to the price of acquiring the product. The environmental parameter identifies the area and severity of the problem that might occur, such as environmental contamination and destruction of property. In relation to environmental severity, the effects of possible accidents may be divided into short term, medium term, long-term and irrevocable consequences. After the evaluation, all of these parameters are used to calculate the hazard index of the product, conforming to equation 4 below.

Seeking to determine the probability of an accident occurring, as a result of a determined hazard, ask yourself the following question: "What is the probability of accidents occurring as a consequence of hazard A?" The possible answers are in table 9 , along with the their respective numerical values in evaluation.

In relation to the personal parameter, injuries caused by accidents are evaluated according to the hazards. This is done by responding to the following questions: "If an accident related to a determined hazard occurs, how many people might possibly be injured?" and "And how severe?" Refer to tables 10 and 11 for evaluative responses. 
Table 9 - Probability of accidents happening as a result of a particular hazard

\begin{tabular}{|c|c|l|}
\hline $\begin{array}{c}\text { Probability of } \\
\text { Occurrence (PO) }\end{array}$ & $\begin{array}{c}\text { Numerical } \\
\text { Value }\end{array}$ & \multicolumn{1}{c|}{ Observations } \\
\hline High & 10 & $\begin{array}{l}\text { High probability of occurrence, hazard is exposed } \\
\text { and risk is imminent }\end{array}$ \\
\hline Medium & 5 & $\begin{array}{l}\text { Probably will occur with frequency, hazard is } \\
\text { partially exposed and risk is elevated }\end{array}$ \\
\hline Low & 3 & $\begin{array}{l}\text { Low probability of occurrence, hazard is } \\
\text { minimally exposed and risk is low }\end{array}$ \\
\hline Remote & 1 & $\begin{array}{l}\text { Will occur with difficulty, hazard is totally } \\
\text { protected and risk is negligible }\end{array}$ \\
\hline
\end{tabular}

To determine environmental damage from each hazard, consider the environment involved and the severity of the damage. Two questions must then be answered: "What would be the are destroyed by a possible accident due to hazard A?" and "And how severe?" The numerical values are described in tables 12 and 13. To determine the largest surface area of the product, consider the two largest dimensions. For example, suppose that the dimensions of a product are $3 \times 5$ $\mathrm{x} 2$, then the greater surface will be 15 units of area. Suppose that the area exposed to destruction due to an explosion is 30 square meters, then the numerical value will be 3 , since the area exposed to destruction is greater than the area of the product.

Table 10 - Numerical values for the people injured in accidents.

\begin{tabular}{|l|c|}
\hline \multicolumn{1}{|c|}{ People Exposed - PE } & Numerical Value \\
\hline $\begin{array}{l}\text { No one is exposed to the hazard and the possibility of injury is } \\
\text { negligible }\end{array}$ & 0 \\
\hline $\begin{array}{l}\text { The number of people exposed to the hazard, who might be } \\
\text { injured, is less than the number of users }\end{array}$ & 2 \\
\hline $\begin{array}{l}\text { The number of people exposed to the hazard, who might be } \\
\text { injured, is equal to the number of users }\end{array}$ & 3 \\
\hline $\begin{array}{l}\text { The number of people exposed to the hazard, who might be } \\
\text { injured, is greater than the number of users }\end{array}$ & \\
\hline
\end{tabular}


Table 11 - Severity of the injuries suffered.

\begin{tabular}{|c|c|l|}
\hline $\begin{array}{c}\text { Severity of the } \\
\text { Injury- GP }\end{array}$ & $\begin{array}{c}\text { Weight } \\
\text { Attributed to the } \\
\text { Severity of the } \\
\text { Injury }\end{array}$ & \\
\hline Light & 1 & $\begin{array}{l}\text { Examples } \\
\text { objects,no need to suspend work. }\end{array}$ \\
\hline Moderate & 2 & $\begin{array}{l}\text { Injuries that incapacitate work for a limited } \\
\text { period of time. }\end{array}$ \\
\hline Severe & 3 & $\begin{array}{l}\text { Definitive occupational disease that makes work } \\
\text { impossible. }\end{array}$ \\
\hline High Severe & 4 & $\begin{array}{l}\text { Permanent invalid status that requires life } \\
\text { assistance, such as paralysis, blindness, coma and } \\
\text { death. }\end{array}$ \\
\hline
\end{tabular}

Table 12 - Area exposed to the hazard and which could be destroyed in an accident.

\begin{tabular}{|l|c|}
\hline \multicolumn{1}{|c|}{ Area Exposed - AE } & Numerical Value \\
\hline The environment is not exposed to hazard & 0 \\
\hline $\begin{array}{l}\text { The area of the environment exposed to the hazard, that } \\
\text { could be destroyed, is less than the larger area of the } \\
\text { product }\end{array}$ & \\
\hline $\begin{array}{l}\text { The area of the environment exposed to the hazard, that } \\
\text { could be destroyed, is equal to the larger area of the } \\
\text { product }\end{array}$ & 2 \\
\hline $\begin{array}{l}\text { The area of the environment exposed to the hazard, that } \\
\text { could be destroyed, is greater than the larger area of the } \\
\text { product }\end{array}$ & \\
\hline
\end{tabular}

To determine the monetary parameter, that indicates the possibility of capital losses resulting from an accident, it is enough to compare the value of possible monetary losses with the cost of acquiring the product and answering the question: "In case of an accident occurring due to hazard A, what would the loss of capital be?" The numerical values are found in table 14 .

It must be kept in mind that the hazards identified and the injuries and damage evaluated are relative to a determined area or group of products. The percentages of importance of the hazards may thus only be applied to products of the same type or with similar characteristics. For example, in evaluating the injuries and damage that may result from using a circular saw one cannot use the data obtained in 
the study of a stove; each product has different characteristics and hazards involved with its use.

Table 13 - Severity of environmental destruction resulting from an accident.

\begin{tabular}{|l|c|l|}
\hline \multicolumn{1}{|c|}{$\begin{array}{c}\text { Severity of } \\
\text { Environmental } \\
\text { Destruction - GA }\end{array}$} & $\begin{array}{c}\text { Weight Attributed to the } \\
\text { Severity of } \\
\text { Environmental } \\
\text { Destruction }\end{array}$ & \multicolumn{1}{|c|}{ Examples } \\
\hline $\begin{array}{l}\text { Immediate or short term } \\
\text { recuperation (up to 1 year) }\end{array}$ & 1 & $\begin{array}{l}\text { Destruction of fences, } \\
\text { walls and small } \\
\text { installations, destruction of } \\
\text { small, planted areas }\end{array}$ \\
\hline $\begin{array}{l}\text { Recuperation over medium } \\
\text { term (between 1 and 10 } \\
\text { years) }\end{array}$ & 2 & $\begin{array}{l}\text { Death of small trees in } \\
\text { reforested areas, } \\
\text { destruction of large } \\
\text { installations }\end{array}$ \\
\hline $\begin{array}{l}\text { Long term recuperation } \\
\text { (between 10 and 100 } \\
\text { years) }\end{array}$ & 3 & $\begin{array}{l}\text { Contamination of water } \\
\text { with detergents or mineral } \\
\text { oils }\end{array}$ \\
\hline $\begin{array}{l}\text { Irrevocable (greater than } \\
100 \text { years) }\end{array}$ & & $\begin{array}{l}\text { Contamination with } \\
\text { radioactive uranium }\end{array}$ \\
\hline
\end{tabular}

Table 14 - Relationship between the value of a product and capital loss resulting from an accident

\begin{tabular}{|l|c|}
\hline \multicolumn{1}{|c|}{ Monetary Parameter - PM } & Numerical Value \\
\hline No loss of capital & 0 \\
\hline Capital loss will be less than the cost of acquiring the product & 1 \\
\hline Capital loss will be equal to the cost of acquiring the product & 2 \\
\hline Capital loss will be greater than the cost of acquiring the product & 3 \\
\hline
\end{tabular}

After determining the points and weighting of the various parameters comes determination of the percentage of importance (IP) for each of the hazards. This is arrived at through equation 1 :

$$
\text { Percentage of Importance }=\mathrm{IP}=\frac{\sum \mathrm{P}}{\sum \mathrm{PTOTAL}}
$$

Where:

$\sum \mathrm{P}=$ sum of points for each hazard, given by equation 2 ;

$\sum$ PTOTAL $=$ total points obtained through hazards, given by equation 3 .

$$
\begin{gathered}
\sum \mathrm{P}=(\mathrm{PExGP}+\mathrm{AExGA}+\mathrm{PM}) \times \mathrm{PO} \\
\sum \mathrm{PTOTAL}=\sum \mathrm{P}_{\text {hazard } 1}+\sum \mathrm{P}_{\text {hazard } 2}+\ldots+\sum \mathrm{P}_{\text {hazard } n}
\end{gathered}
$$


Calculation of the point total obtained through the hazards allows evaluation of how many of these contribute to accidents. To do this, it is necessary to determine the maximum sum of possible points, representing the value that would be obtained if all the related hazards contributed to an accident and such an accident had the worst possible consequences. This sum is obtained by multiplying the sum of the maximum points possible for a hazard - given by the maximum numerical values from tables 9 to 14 , a value equal to 270 - by the number of hazards associated with safety. The contribution of the hazards to an accident, called the hazard index of the product (IPP) is given by equation 4 .

$$
\mathrm{IPP}=\frac{\sum \mathrm{PTOTAL}}{\sum \mathrm{PMAX}}
$$

Where:

$\sum$ PTOTAL $=$ total of the points obtained through hazards;

$\sum \mathrm{PMAX}=$ maximum sum of possible points, given by equation 5 .

$$
\sum \mathrm{PMAX}=270 \times \mathrm{NPR}
$$

Where:

$\mathrm{NPR}=$ number of related hazards.

With the percentage values of the importance of hazards, the designer can verify which hazards are more critical and decide how he can reduce the level of this hazard, which will result in improved safety of the product being designed. Using the data in table 15, the IPP of the product in question may be calculated as:

$$
\mathrm{IPP}=\frac{134}{(270 \times 5)}=0.0992
$$

In this example, the hazard index of the product (IPP) is 0.0992 or $9.92 \%$. 
Table 15 - Example of evaluation of injuries and damage resulting from a product

\begin{tabular}{|l|l|l|c|c|c|c|c|c|c|c|}
\hline Hazards & $\begin{array}{l}\text { Subsystems or } \\
\text { Components }\end{array}$ & $\begin{array}{l}\text { Injuries and } \\
\text { Damage }\end{array}$ & PO & PE & GP & AE & GA & PM & $\Sigma$ P & IP \\
\hline $\begin{array}{l}\text { Cutting } \\
\text { Edges }\end{array}$ & Saw & Cuts & 10 & 2 & 2 & 0 & 0 & 1 & 50 & 37 \\
\hline $\begin{array}{l}\text { High noise } \\
\text { level }\end{array}$ & Motor & Hearing loss & 5 & 3 & 3 & 0 & 0 & 3 & 60 & 45 \\
\hline $\begin{array}{l}\text { Leakage of } \\
\text { Hydraulic } \\
\text { oil }\end{array}$ & Braking System & $\begin{array}{l}\text { Soil } \\
\text { contamination }\end{array}$ & 1 & 0 & 0 & 3 & 3 & 3 & 12 & 9 \\
\hline $\begin{array}{l}\text { Thermal } \\
\text { lock }\end{array}$ & Structure & $\begin{array}{l}\text { Equipment } \\
\text { stopped }\end{array}$ & 1 & 0 & 0 & 0 & 0 & 3 & 3 & 2 \\
\hline $\begin{array}{l}\text { Deficient } \\
\text { software } \\
\text { control }\end{array}$ & $\begin{array}{l}\text { Control } \\
\text { Subsystem }\end{array}$ & Fall in sales & 3 & 0 & 0 & 0 & 0 & 3 & 9 & 7 \\
\hline $\begin{array}{l}\text { Legend: } \\
\text { IP - Percentage of importance (\%) } \\
\sum \text { P- Sum of points for each hazard }\end{array}$ & & & & & & & & & & \\
\hline
\end{tabular}

After elaboration of the list of requirements and the definition of the basic characteristics of the product in the design process, recalculation of the hazards of the product is recommended, as shown in table 15 , in order to verify if the identification of hazards in similar products was exhaustive and whether these have been eliminated or controlled in the new product. With this, we can compare the hazard calculated previously with that calculated after the product is ready and verify whether application of the method was effective in the determining safety needs and in the introduction of better safety in the product.

\subsection{Verifying the Existence of Applicable Norms}

The choice of applicable norms for the product or its specified hazards is one of the most important tasks for a safe design, due to these being selected before any definition or specification of the design components, as this will probably affect these activities. Safety norms for designs can limit product characteristics like surface temperature of the machine and dimensions of the openings through which access is gained to hazardous parts. The use of applicable norms guarantees that the product will have a minimal acceptable level of safety and help smooth decisions and specifications regarding the design. 


\subsection{Establishing Guidelines}

The objective of establishing guidelines and directives is to orient towards the development of safer products. Guidelines for the design of products identify the wishes of the designer and the manufacturer in establishing product safety levels, denoting, at times, the company's safety policy. These seek to establish parameters for guaranteeing that accidents be avoided or at least have less consequences, orienting the designer towards developing products with good safety levels. The guidelines found in the bibliography (Nutter, 1984) (Main 1996) (Weinstein, 1997) (AR 385-16, 1990) (EN 292, 1991) (Priest, 1998) are similar enough to point to the following basic principles:

- Whenever possible, design, manufacture and distribute products that are free of unsafe features;

- If this is not possible, construct barriers and protections for protecting people from unsafe features of the product;

- If this too is not possible, provide the user with adequate instructions and warnings;

- Deal with similar hazards and risks of a product in a uniform way;

- Limit the consequences of accidents in relation to the following aspects: the product must not kill or injure people, animals or plants and must not damage either property or the environment.

These are guidelines that can always be used in determining the needs and formulation of safety requirements. Besides this, they consider the standards commonly accepted by people, as well as legal issues. The guidelines cited are inserted into the concept of safety, according to which it is the accident itself that must first be avoided, followed by injury and damage. Generalizing these guidelines, we may observe that they signify the following basic structure: physical or operational characteristics of the product, even when under external influence, cannot cause damage or injury. Examples of hazards with their causes and consequences are listed in table 16; in which it is said whether the hazard is inherent to the product or can be eliminated, along with the applicable norms and guidelines. 
After verifying which hazards can be eliminated and which are inherent to the product, their respective guidelines can be applied. Special attention must be given to those hazards with a greater percentage of importance. With the recommendations and orientations in the norms pertinent to the product and the hazards, these last can be reduced.

Table 16 - Examples of hazards in product and usable guidelines and norms

\begin{tabular}{|l|l|l|l|l|l|}
\hline Hazards & $\begin{array}{l}\text { Subsystems or } \\
\text { Components }\end{array}$ & $\begin{array}{l}\text { Injuries or } \\
\text { Damage }\end{array}$ & IP & $\begin{array}{l}\text { Inherent or } \\
\text { Removable }\end{array}$ & $\begin{array}{l}\text { Applicable Norms } \\
\text { and Guidelines }\end{array}$ \\
\hline $\begin{array}{l}\text { High noise } \\
\text { level }\end{array}$ & Motor & $\begin{array}{l}\text { Hearing } \\
\text { loss }\end{array}$ & 45 & Inherent & Protect the operator \\
\hline Sharp edges & Saw & Cuts & 37 & Inherent & $\begin{array}{l}\text { Protect and warn } \\
\text { operator NBR 13928 }\end{array}$ \\
\hline $\begin{array}{l}\text { Leakage of } \\
\text { hydraulic oil }\end{array}$ & $\begin{array}{l}\text { Braking } \\
\text { Subsystem }\end{array}$ & $\begin{array}{l}\text { Soil } \\
\text { contaminati } \\
\text { on }\end{array}$ & 9 & Removable & Eliminate the leak \\
\hline $\begin{array}{l}\text { Deficient } \\
\text { control by } \\
\text { software }\end{array}$ & $\begin{array}{l}\text { Control } \\
\text { subsystem }\end{array}$ & $\begin{array}{l}\text { Loss of } \\
\text { sales }\end{array}$ & 7 & Removable & Eliminate the problem \\
\hline Thermal lock & Structure & $\begin{array}{l}\text { Stopped } \\
\text { equipment }\end{array}$ & 2 & Removable & Eliminate the problem \\
\hline
\end{tabular}

\subsection{Determining the Safety Needs of Users}

The objective in this stage is to determine the safety needs of users in relation to the safety of the product, defining adequate requirements. By safety needs it is understood that it is absolutely vital to guarantee that, with the product, no accident of any type occur; this good safety is an aspect of quality and satisfies both the consumer and the user.

The requirements of the design correspond to the demands the product will have to satisfy and originate in the needs of the user, the technical and operational needs of the company and in market factors. The list of requirements points to the design process with the intention of guaranteeing that the product will come to have the desired characteristics.

Users normally have difficulty in explaining their needs, which have to be translated into design specifications. Optimal products are those that attend to the real needs of the users; in these the requirements are transformed into characteristics. 
Because of this, a well-elaborated list of requirements that considers the needs of the user and consumer is a vital, initial step for any good product.

Should there be inherent hazards in the function of a product, and if there are no other solutions to safer principles, then it falls to the user to control risks. In order to eliminate hazard or control risks, the requirements for such must be sufficiently formulated and have their correct values attributed. Often, these values are determined by industrial norms and standards, as seen in item 2.5. These requirements must then be opposed to the occurrence of accidents or try to diminish the possibilities of their consequences. That being the case, in order to obtain safer products, at least one safety requirement must be formulated for each hazard.

The product in use forms a system with the user, the human-machine system. Among the safety necessities, there are also the relationships within this system, which means that the design should consider operational aspects of the product, as well. This includes illumination of the means of information, loads, colors and contrasts, work place dimensions and other aspects relative to Safety and Ergonomics.

A need expresses an aspect of quality in a product, in the case of elimination of hazard and/or a reduction in injury and damage. Examples of safety needs are listed in table 17. Thus, the requirements must be formulated through sentences that express the needs of the user in relation to safety, presenting reference values obtained through information gathered from technical catalogues, analysis of competitive products and from researched norms. For example, in thermal machines, where the hazard of burns is inherent and cannot be eliminated, surface temperatures in contact with the operator can be limited to $43^{\circ} \mathrm{C}$. This limit constitutes a quantitative requirement of the design. 
Table 17 - Examples of safety needs of a product

\begin{tabular}{|l|l|l|}
\hline $\begin{array}{c}\text { Component or } \\
\text { Subsystem }\end{array}$ & \multicolumn{1}{|c|}{ Hazard } & \multicolumn{1}{c|}{ Safety Need } \\
\hline Saw & Cutting edge & $\begin{array}{l}\text { The saw must be prevented from contacting the } \\
\text { user, there must be warnings about this hazard }\end{array}$ \\
\hline Motor & High noise level & $\begin{array}{l}\text { The saw must be enclosed or isolated in order to } \\
\text { limit the noise to the operator to 70dB(A). }\end{array}$ \\
\hline Braking & $\begin{array}{l}\text { Leakage of } \\
\text { hydraulic oil }\end{array}$ & Parts that use hydraulic oil must be confined \\
\hline Structure & Thermal lock & $\begin{array}{l}\text { The structure must be of material that resists } \\
\text { tensions arising from temperature variations } \\
\text { between } 20^{0} \text { and } 60^{\circ} \mathrm{C}\end{array}$ \\
\hline Control & $\begin{array}{l}\text { Deficient control } \\
\text { by software }\end{array}$ & $\begin{array}{l}\text { Software must not be able to execute critical } \\
\text { operations without the user accompanying them, } \\
\text { informing and demanding permission for each new } \\
\text { operation. }\end{array}$ \\
\hline
\end{tabular}

\section{Conclusions}

This work presented a method for determining the safety needs for products. Its intention was to use information derived from safety problems in products, which was then associated with other information in a series of intermediate stages in order to understand what information can determine the needs of users and translating those needs into safety requirements of products, thus enabling real improvement in their safety.

This method constitutes a logical procedure for the obtainment of safety needs, subdivided into stages. The first two constitute comprehension of safety deficiencies presented by products. The latter stage, determination of possible injuries and damage, consists of evaluation of the possible consequences of accidents, resulting in how these manifest themselves and in the relative importance of each hazard. The stages of verification of applicable norms and the establishment of guidelines indicate how to avoid accidents by limiting hazards and their consequences. From this we can start to formulate safety needs and transform them into design requirements.

In this method, an evaluation of product hazard (Carpes Jr., 2001) is made, realized for an old product and for a new one in its design phase. Decreased hazard of a new product should be reflected in a reduction of the number and severity of 
accidents associated with it. This will make the safety index of the new product better than that of the old.

\section{References}

(AR 385-16, 1990) Army Regulation 385-16. System Safety Engineering and

Management. Washington, DC: Department of Army, May 3, 1990.

(Carpes Jr., 2001) Carpes Jr., Widomar Pereira. Análise da Seguranca Humana

para Desenvolvimento de Produtos mais Seguros. Tese de Doutorado.

Florianópolis: Universidade Federal de Santa Catarina, 2001. 251p.

(EN 292, 1991) EN 292. Safety of Machinery - Basic Concepts, General Principles

for Design - Part 1: Basic Terminology, Methodology. Brussels: European

Committee for Standardization (CEN), 1991.

(Main, 1996) Main, Bruce W. Safer by Design. Machine Design. September 26, 1996. Pg 8103-107.

(Nutter, 1984) Nutter, James W. Designing with product liability in mind. Machine Design, 24 de maio 1984. Pg. 57-60.

(Weinstein, 1997) Weinstein, Alvin S. Reducing Risk in product liability: common sense returns to product liability laws. Machine Design, 8 maio de 1997. Pg 95-98. 